\title{
Annual crops for forage in the Alberta parklands
}

630.72

C759

C 88-1

c. 3 


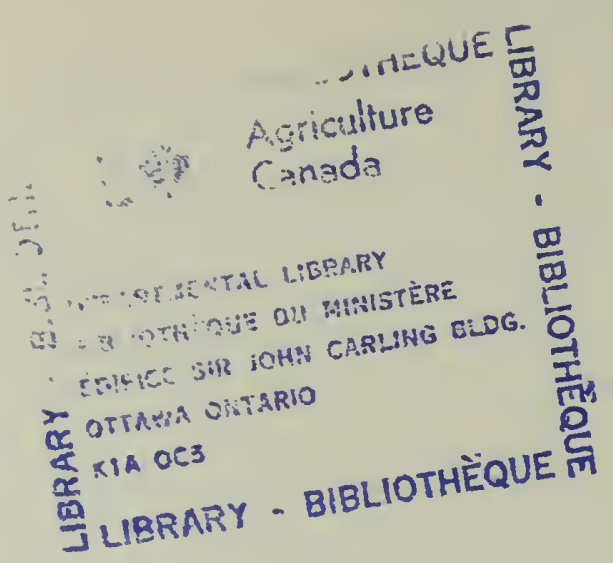




\section{Annual crops for forage in the Alberta parklands}

B. BERKENKAMP

Research Station, Agriculture Canada

Melfort, Saskatchewan

J. MEERES

Research Station, Agriculture Canada

Lacombe, Alberta

Technical Bulletin 1988-1E

Research Branch

Agriculture Canada

1988 
Copies of this publication are available from

Director

Research Station

Research Branch, Agriculture Canada

Box 1240

Melfort, Sask.

SOE $1 \mathrm{~A} 0$

Produced by Research Program Service

(C) Minister of Supply and Services Canada 1988

Cat. No.: A54-8/1988-1E

ISBN: 0-662-15764-8 


\section{CONTENTS}

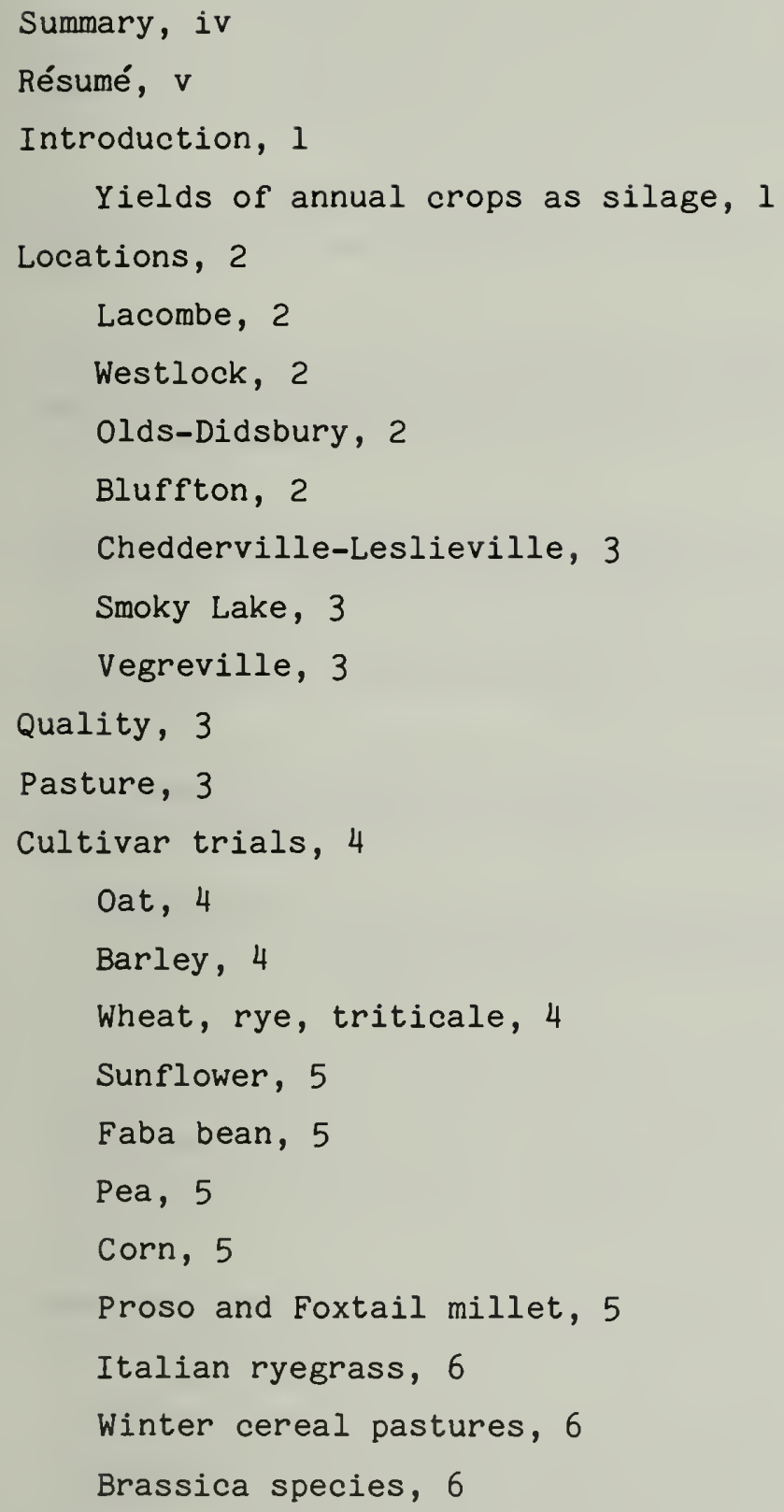




\section{SUMMARY}

The annuals for forage program was begun in 1979 and completed in 1983. Work in the southern part of Alberta, covering the Brown and Dark Brown soil zones, both irrigated and dryland, was carried out from the Alberta Horticulture Research Centre at Brooks. The Black and Gray Wooded soil zones were covered from the Agriculture Canada Research Station, Lacombe, by the use of six off-station locations. The productivity of various crops and cultivars was evaluated at several locations, and the following conclusions were drawn.

- Oat was the highest yielding silage crop. Foothill was the best cultivar, particularly on Gray Wooded soils, followed by Fraser, Laurent, Sentinel, and Grizzly.

- Sunflower was the second highest yielding crop, but it cannot be recommended because of extreme variability in yield between locations and years, as well as difficulties in harvesting with cereal or haying equipment.

- Triticale produced good yields, particularly Triwell and several breeders' lines, whereas Rosner and Welsh were somewhat lower yielding.

- Wheat cultivars yielded less than triticale; Wakooma, Pitic, and Glenlea were the better yielding cultivars.

- Barley was of higher quality than the other cereals, containing more protein and less fiber. Johnston was the highest yielding barley cultivar.

- Spring rye was lower yielding than barley; Petkus II, a line from Swift Current Research Station, outyielded other rye cultivars.

- Corn was low yielding because of insufficient heat units.

- Faba bean and pea had the highest percentage of protein and should be used to increase the protein content of silage crops. Faba bean was better on Black soils and had the advantage of an upright growth habit, but pea was higher yielding on Gray Wooded soils.

- A multiple-cut system was used to estimate pasture yield, by cutting each time the regrowth reached $25-30 \mathrm{~cm}$ in height. Oat was the highest yielding crop as pasture on Gray Wooded soils; however on Black soils, spring-planted Italian ryegrass, winter wheat, and fall rye were more productive than oat. Spring cereals produced good yields early in the season, with growth declining in the fall, whereas spring-planted winter crops and ryegrass started slowly and produced high yields later in the season.

- Forage rape, fodder radish, and kale produced high yields if not grazed until late fall. 
RÉSUME

Le programme sur les annuelles fourragères a commencé en 1979 et a pris fin en 1983. Les travaux dans le sud de l'Alberta sur les zones de sols bruns et brun foncé, irrigués et non irrigués, ont été effectués à partir du Centre de recherches horticoles de l'Alberta, à Broolis. Les zones de sols noirs et forestiers gris ont été étudiées à partir de la Station fédérale de recherches agricoles de Lacombe par le choix de six emplacements hors station. Les chercheurs ont évalué la productivité de divers cultivars et cultures à plusieurs emplacements et ont tiré les conclusions suivantes:

L'avoine est la plante à ensilage la plus productive. Foothill est le meilleur cultivar, en particulier sur sols forestiers gris, suivi par Fraser, Laurent, Sentinel et Grizzly.

Le tournesol vient après l'avoine pour la productivité, mais ne peut être recommandé à cause d'une extrême variabilité de rendement d'un endroit et d'une année à l'autre, et des difficultés de récolte à la moissonneuse ou à la ramasseuse-presse.

Le triticale donne de bons rendements, en particulier Triwell et plusieurs lignées d'obtenteur, alors que Rosner et Welsh s'avèrent moins productifs.

Les cultivars de blé affichent un rendement moindre que le triticale; Wakooma, Pitic et Glenlea s'avèrent les meilleurs.

L'orge est de meilleure qualité que les autres céréales, avec une teneur plus élevée en protéines, mais plus faible en cellulose. Johnston est le cultivar le plus productif.

- Le seigle de printemps est moins productif que l'orge; Petkus II, lignée de la Station de recherches de Swift Current, surpasse les autres cultivars de seigle.

Le malis est de rendement modeste à cause de l'insuffisance d'unités thermiques.

La féverole et le pois affichent la plus forte teneur en protéines et devraient servir à relever la concentration protéique des cultures à ensilage. Le féverole donne de meilleurs résultats sur sols noirs et a l'avantage d'avoir un port dressé, mais le pois est plus productif sur sols forestiers gris.

- Un régime multicoupe a servi à évaluer le rendement des pâturages en coupant la repousse dès qu'elle atteint 25 à $30 \mathrm{~cm}$ de hauteur. L'avoine est la plante à pâturage la plus productive sur sols forestiers gris, mais sur sols noirs, le ray-grass d'Italie semé au printemps, le blé d'hiver et le seigle d'automne surpassent l'avoine. Les céréales de printemps donnent de bons rendements tôt dans la saison, mais elles régressent à l'automne, alors que les cultures d'hiver et le ray-grass semé au printemps démarrent lentement, mais donnent des rendements élevés plus tard en saison.

Le colza, le radis et le chou fourragers donnent de bons rendements s'ils ne sont pas pâturés avant la fin de l'automne. 



\section{INTRODUCTION}

There has not been a critical evaluation of the role of annual crops for forage in Alberta in spite of its position as the major beef-producing province in Canada. Researchers working with forage are primarily interested in perennial grasses and legumes. Interest in annual crops has been oriented primarily toward grain production. This emphasis has resulted in a lack of information on annual forage production, particularly beyond the area in southern Alberta, where corn is recommended. The increased intensity of cropping, brought on by higher land values, has prompted some producers, particularly dairy operators, to grow annuals. Beef producers must also compete with producers in areas with a mild climate, which allows year-round use of rangeland as pasture. Annual crop residues, both in-field and stored, have been and will probably continue to be a source of low-quality feed. Annual crops for forage offer several advantages of perennials, such as higher production, lower harvest and storage losses when ensiled, and a choice of forage or grain production. However, there are several disadvantages, including the following: a requirement for better storage facilities, higher labor requirements for tillage and harvest, and transportation difficulties, which limit silage to on-farm use.

The annuals for forage program was designed to cover the Black and Gray Wooded soil-climatic zones. A primary aim was to establish the potential of various species for forage production and to evaluate cultivars from diverse sources.

All annuals were seeded in small plots $(1.2 \times 6.0 \mathrm{~m})$ and harvested to determine fresh weight; a subsample was oven-dried to determine dry weight yield as kilograms per hectare. The dried samples were used to determine protein content and acid detergent fiber, from which digestible energy content was estimated.

From 1979 to 1983 this work was supported by a grant from the Farming for the Future program.

\section{Yields of annual crops as silage}

Several tests were begun in 1979 to evaluate the production of forage by annual crops. Single entries of 13 crops were tested for silage production at Lacombe and Bluffton in 1979 and 1980 (Table 1). Results indicated that sorghum and soybeans not be tested further because of low yields, that forage rape be tested separately, and that corn be added to the standard test.

The standard test crops for silage production were grown at six or seven locations in central Alberta for 5 years and included several cultivars of five cereals as well as corn, faba bean, pea, and sunflower. Table 2 shows the silage yields in kilograms of dry matter per hectare from all locations for each year. The variation from year to year can be seen, as well as deletions and additions of cultivars. The average species yield, which is calculated from all the cultivar-year yields, gives a good estimate of yields in central Alberta.

The yields of crops in the standard tests over 5 years showed strong similarities based on soil type. The yields from the Black soil locations (Lacombe, Westlock, and Olds-Didsbury) were combined, as were those from the Gray Wooded soil locations (Bluffton, Smoky Lake, and CheddervilleLeslieville). The only Solonetzic soil location was Vegreville. Table 3 
shows these yields as a percentage of Foothill oats for each soil type in addition to the actual yields from the three soil types. These data demonstrate the need for recommendations based on soil-climatic zones.

\section{LOCATIONS}

The yields of the standard tests at various locations are shown in Tables 4-10. Averages are not listed for crops grown for only 1 year. The 1979 growing season was dry at all locations, which resulted in low yields (Table 2). Fertilizer was applied at all sites in 1979. Nitrogen was applied at 50 $\mathrm{kg} / \mathrm{ha}$ on Black soil sites and at $75 \mathrm{~kg} / \mathrm{ha}$ on Gray Wooded soil sites as ammonium nitrate $(34-0-0) ; 25 \mathrm{~kg} / \mathrm{ha}$ of $\mathrm{P}_{2} \mathrm{O}_{5}$ (11-55-0) were also applied at all sites.

The 1980 season was dry at seeding, but adequate rainfall throughout the rest of the growing season resulted in good yields at most locations.

Fertilizer applications to the standard tests in 1980 were the same as in 1979, except at Olds, where the cooperator applied anhydrous ammonia as the sole source of nitrogen. Beginning in 1981 soils from all sites were analyzed for plant nutrient content, and fertilizer was then added based on recommendations from the Alberta soil-testing laboratory.

Lacombe

All the test crops were grown at the Agriculture Canada Research Station, which was used as the primary test area. This site, with its fertile black neutral soil was considered to be representative of the Black soil zone. A dry year in 1979 and a severe hailstorm on 2 August 1980 were major yield-reducing factors. The forage yields are shown in Table 4.

\section{Westlock}

The Westlock site was about $13 \mathrm{~km}$ northwest of Westlock, on a Black soil that was slightly acidic, at $\mathrm{pH} \mathrm{6.2.} \mathrm{The} \mathrm{yields} \mathrm{here} \mathrm{were} \mathrm{somewhat} \mathrm{lower} \mathrm{than}$ those from Lacombe as shown in Table 5. In 1983 more than the recommended amount of fertilizer was applied in error.

\section{Olds-Didsbury}

The Olds site was on Black soil, about $24 \mathrm{~km}$ west of olds, and was used as a test location in 1979 and 1980. In 1980 the cooperator applied ammonia, and no additional nitrogen was added. From 1981 to 1983 the plots were grown on a similar Black soil with a $\mathrm{pH}$ of 6.0 , located about $32 \mathrm{~km}$ west of Didsbury (Table 6). In 1983 a light frost on 20 July slightly injured the leaves of the corn but did not appear to reduce yields.

\section{Bluffton}

This site, about $10 \mathrm{~km}$ north of Bluffton, was considered to be representative of the Gray Wooded soil zone (Table 7). The soil was slightly acidic, with a $\mathrm{pH}$ about 6.0 , and was low in both potassium and sulfur. Because of its proximity to Lacombe, this site was used for most variety trials on Gray Wooded soils. 
Chedderville-Leslieville

Chedderville, a Gray Wooded soil site about $19 \mathrm{~km}$ south of Rocky Mountain House, was used as a test site in 1979, 1980, and 1981. This soil was distinctly acidic, with a $\mathrm{pH}$ of 5.3. The plots in 1981 were grown on an area summerfallowed in 1980, which resulted in unusually high yields, as shown in Table 8. In 1982 and 1983 the plots were grown at Leslieville, which is about $19 \mathrm{~km}$ east of Rocky Mountain House, on a soil type that was similar but less acidic, with $\mathrm{pH}$ at about 6.5. In 1982 hail damaged the plots in mid August, severely reducing potential yields.

\section{Smoky Lake}

This site was about $10 \mathrm{~km}$ east of Smoky Lake on Gray Wooded soil with a $\mathrm{pH}$ of 7.5. In 1983 the plots were moved north to a similar soil type with a $\mathrm{pH}$ of 6.5 , but a dry spring reduced yields, as shown in Table 9 .

\section{Vegreville}

The Agriculture Canada substation at Vegreville was used for plots from 1981 to 1983. This site was selected as representative of Solonetzic soils. This soil is high in sodium, particularly below the top $15 \mathrm{~cm}$. Total soluble salt and sulfate concentrations increase with soil depth to greater than 1000 ppm, or 7.4 mmo conductivity at the 30-60 cm depth. These salt concentrations can reduce crop growth, as shown in Table 10.

\section{QUALITY}

Analysis of annual forages for protein showed considerable year-to-year variation as well as differences between sites (Table 11). As expected, faba bean and pea contained the highest percentage of protein. Of the cereals, barley was the highest, followed by wheat, triticale, oat, and rye, respectively. Sunflower averaged slightly higher than barley, and corn was slightly higher than oat. Percentage of protein was combined with dry-matter yield to estimate actual yield of protein for each crop averaged over 4 years (Table 12). Faba bean and pea produced the most protein, followed by sunflower and oat.

Analysis for fiber allowed digestible energy to be estimated. Dry-matter yields combined with digestible energy per kilogram of dry matter gave an estimate of yields of digestible energy per hectare for each species (Table 13). Averaged over 4 years, oat produced the highest quantity of digestible energy followed by sunflower, triticale, wheat, and barley. Faba bean and pea had the lowest yields of digestible energy.

\section{PASTURE}

Multiple cuts to simulate grazing were made on plots at Lacombe and Bluffton from 1979 to 1983. The crops were cut back to $5 \mathrm{~cm}$ each time they reached a height of $25-30 \mathrm{~cm}$. At Lacombe, Italian ryegrass consistently gave the highest pasture yields except in the dry season of 1979. Winter cereals produced good pasture yields at Lacombe, whereas oat was consistently the best pasture at Bluffton (Table 14). Triwell replaced Welsh triticale in 1982 because of its higher yield in variety tests, and Halton winter barley was added in 1982. At Lacombe, Halton produced $80 \%$ more pasture than Bonanza in the 2 years they were tested together, whereas at Bluffton, their yields were 
similar. The crops could easily be divided into early and late season producers. Spring cereals showed more rapid growth in the spring and were ready for pasturing earlier. Italian ryegrass and winter-type cereals grew most rapidly in midsummer and continued to produce well into the fall when moisture was adequate.

\section{CULTIVAR TRIALS}

Oat

Oat cultivar trials were carried out at Lacombe from 1979 to 1983 and included Foothill, licensed in 1978 as a forage oat, for comparing yields. Silage yields of common cultivars are shown in Table 15. Less known, foreign and breeders' lines of oat are shown in Table 16. The 1980 cultivar trials at Lacombe were damaged by hail, which reduced yields.

At Bluffton, yields were somewhat lower than at Lacombe. Cultivars and lines are shown in Table 17 for 1981-1983.

Currently recommended cultivars for silage in the parklands, in descending order of yield, are as follows: Foothill, Laurent, Frazer, Grizzly, Harmon, and Cascade.

\section{Barley}

Barley is the most commonly used silage crop in the parkland region. This is a result of several factors, including familiarity to producers, choice of seed or silage crop, and availability of seed. Earliness does not interfere with other operations and produces feed that has a higher protein content than do other cereal crops (Table 11). For comparison, Bonanza was selected as a check. Table 18 shows the yields of variety trials carried out at Lacombe. When first tested in 1980, Johnston did not produce the highest yield, but it did rise to first place at both Lacombe and Bluffton for the following 3

years. Yields of barley at Bluffton, as shown in Table 19, are considerably below those at Lacombe. The currently recommended barley cultivars for silage are Johnston, Empress, and Klages in central and northern Alberta; and Johnston, Galt, Klondike, Elrose, and Hector in south and east-central Alberta.

Wheat, rye, and triticale

Wheat, rye, and triticale cultivars were compared in a single test each year from 1980 to 1982 at Lacombe (Table 20) and in 1981 and 1982 at Bluffton (Table 2l). In 1983 triticale was tested separately from wheat at both locations.

Cultivars of spring rye were limited to Prolific and Gazelle, with Gazelle producing higher silage yields. Three lines selected from Petkus at Swift Current were tested in 1980 (Table 20). One line, Petkus II, was the highest yielding and with Gazelle was added to the standard test. The testing of wheat, rye, and triticale cultivars took place in 1981 and 1982 at Lacombe and Bluffton (Tables 20 and 21). Rye produced yields similar to wheat and somewhat lower than triticale.

The wheat cultivars Glenlea and Pitic were used in the standard test as checks. When compared with other utility wheats and with hard red spring and durum wheats, they showed similar yields at Lacombe in 1980. It is common practice to salvage grain crops of wheat or rye damaged by drought, hail, or frost for forage, although these crops are not purposely seeded for that use. 
The triticale cultivars Rosner and Welsh were used in the standard test beginning in 1979, until the better yielding Triwell was added in 1981. In 1981 and 1982 Triwell was the highest producing cultivar at Bluffton (Table 21) and in 1982 at Lacombe (Table 20). The cultivars Triwell and Carman are recommended for silage production in the parkland region.

\section{Sunflower}

Sundak sunflower in the standard test produced highly variable forage yields in various years and locations (Tables 2-10). A similar variability was found in the cultivar test at Lacombe over the years 1979-1983 (Table 22). Kenya White, introduced and supplied by Morden Research Station, produced the highest total yield. The cultivar is very tall $(3 \mathrm{~m})$ and difficult to harvest, as would be most other cultivars whose stem base has a diameter of up to $60 \mathrm{~mm}$. The low yields in 1980 were partly due to hail damage. Although sunflowers have a potential for high silage yield, year-to-year variability and potential harvest problems restrict their use as a silage crop.

Faba bean

Faba bean cultivars and lines were evaluated at Lacombe from 1980 to 1983 (Table 23). The cultivars Herz Freya, Aladin, and Outlook were good forage producers, Diana was somewhat lower, and Ackerperle was the lowest producer. Orion and Lacombe No. 3 were selected for seed yield and earliness, and do not yield as well for forage. The faba bean test was grown at Bluffton in 1981, 1982, and 1983 as well as at Vegreville in 1982 and 1983; yields are shown in Table 24. Faba bean outyielded peas on Black soils, but on Gray Wooded and Solonetzic soils, pea usually produced more than did faba bean. Faba bean has the advantage of an upright growth habit and a slightly higher protein content, 17-20\%, when compared with peas at 16-17\%.

Pea

Pea cultivars were evaluated for silage yield for the years 1980-1983 (Table 25). Generally, the cultivars Tara, Century, and Lenca yielded better than did Trapper and Triumph. Pea should be used as a source of high protein in mixtures or should be combined with low-protein silage crops in the Gray Wooded soil areas, where it produces very well.

Corn

Cultivars of corn were evaluated at Lacombe over 3 years for silage yield (Table 26). In 1981 the yields were very good, and in 1983 they were very low. This variation was also found with corn in the standard test between years and locations. In 1982 North American and European hybrids were compared, but neither group had a yield advantage. Corn cannot be recommended in short-season areas because of its variable yields and the requirement for specialized harvesting equipment.

Proso and Foxtail millet

Ten lines of Proso millet and eight lines of Foxtail millet from Morden, Man., were evaluated for silage yield at Lacombe in 1981 and 1982 (Table 27). Good silage yields were found in 1981 for some of the lines, but they did not 
mature to produce seed. The earliest line, NC22-3, does occasionally produce mature seed, but both types are extremely frost sensitive and are not adapted to the parkland area's short season.

\section{Italian ryegrass}

Four cultivars of Italian ryegrass were evaluated at Lacombe for their silage (two cuts), hay (three cuts), and pasture (four or five cuts) production from 1981 to 1983 (Table 28). They mature earlier than cereals, and when cut as silage at the soft-dough stage, sufficient regrowth occurred to warrant a second cut. The hay cuts were made shortly after heading and resulted in three cuts. As simulated pasture, the plots were cut each time the growth reached $30 \mathrm{~cm}$, which resulted in four or five cuts. The highest yields were found as silage, with the exception of Lemtal in 1981 and Lemtal, Maris Ledger, and Merwester in 1982. In general, Promenade was the best silage cultivar, Merwester the best for hay, and Maris Ledger the best for pasture. All cultivars under the three types of harvest produced lower yields in 1983 because of a dry spring and fall. Ryegrasses are perennials in areas with mild climates, but in Alberta they must be considered annuals, as they do not survive the winter.

\section{Winter cereal pastures}

The pasture yields of spring-planted cultivars of winter wheat, triticale, and fall rye were evaluated at Lacombe in 1983 (Table 29). The total pasture yield of Norstar winter wheat was the lowest, an unexpected occurrence because it has regularly outyielded fall rye in pasture production in previous years. Sundance, followed by Kodiak, produced the highest first-cut yields, whereas Winalta produced more in the second and third cuts. Norstar produced the second lowest yield in the first cut and the lowest yield in the third cut. The spring and fall of 1983 were very dry, and Norstar may require better conditions to reach its potential productivity.

\section{Brassica species}

Several species of brassica crops were compared with canola for forage yield under a two-cut system (pasture) and a single-cut system (silage) late in the season, on 1 October (Table 30). Several crops produced good yields under the single-cut system, but none produced satisfactory regrowth when cut on 29 July. Appin grazing turnip produces fleshy roots, and cut 2 includes root weight. Very high yields were recorded for most of these cultivars in 1983 (Table 31). Altex, Tobin, Apoll, and Neris changed from vegetative growth to flowering and were cut on 29 July in the silage test. The others did not flower and continued to grow until cut on 14 september, at which time any regrowth from those cut 29 July was also harvested.

For pasture the first cut was taken on 4 July. Two more cuts were taken from the cultivars that showed sufficient regrowth, one on $26 \mathrm{July}$ and the last on 16 september. The remaining cultivars regrew very slowly after the first cut, and a second cut was not taken until 16 September.

The brassica crops were regularly damaged in the spring by flea beetles, and occasionally this attack was severe enough to require the use of insecticide sprays. Cabbageworms were found on brassica in the fall but not in sufficient numbers to warrant control measures. 
Frost-tolerant brassica crops are useful only as late fall pasture since they continue to produce very late in the fall if they are not harvested earlier. Their use as silage is not practical because of the late harvest of material with very high moisture content. 
Table 1. Silage yield of species at Lacombe and Bluffton for 1979 and 1980, in kilograms per hectare of dry matter

\begin{tabular}{|c|c|c|c|c|}
\hline & \multicolumn{2}{|c|}{ Lacombe } & \multicolumn{2}{|c|}{ Bluffton } \\
\hline & 1979 & 1980 & 1979 & 1980 \\
\hline Foothill oat & 11962 & 10329 & 4955 & 10118 \\
\hline Bonanza barley & 7657 & 10061 & 3111 & 3543 \\
\hline Welsh triticale & 10123 & 13383 & 3456 & 6309 \\
\hline Glenlea wheat & 10128 & 12041 & 2511 & 7209 \\
\hline Diana faba bean & 5956 & 6995 & 1602 & 4873 \\
\hline Tara pea & 6933 & 5463 & 2269 & 1705 \\
\hline G4077 corn & 5770 & 9896 & 1029 & 4274 \\
\hline Pioneer 931 sorghum & 5004 & 6172 & 249 & 167 \\
\hline Sundak sunflower & 11299 & 5468 & 2275 & 4121 \\
\hline Maple Arrow soybean & 2602 & 1232 & 521 & 91 \\
\hline NC22-3 Proso millet & 6433 & 6203 & 494 & 317 \\
\hline Gazelle spring rye & 3059 & 12336 & 703 & 6480 \\
\hline Dwarf Essex rape & & 16971 & & 11402 \\
\hline
\end{tabular}


Table 2. Silage yield of annual forage crops in Central Alberta, in kilograms per hectare, at six locations in 1979 and 1980 and seven locations in 1981-1983

\begin{tabular}{|c|c|c|c|c|c|c|c|}
\hline Crop & 1979 & 1980 & 1981 & 1982 & 1983 & $\begin{array}{l}\text { Yearly } \\
\text { average }\end{array}$ & $\begin{array}{c}\text { Average } \\
\text { species yield }\end{array}$ \\
\hline \multicolumn{8}{|l|}{ Barley } \\
\hline$\overline{\text { Betzes }}$ & 5164 & 6537 & & & & 5851 & \multirow{6}{*}{$\begin{array}{c}\text { (barley } \\
6184 \text { ) }\end{array}$} \\
\hline Klondike & 5371 & 6240 & 6108 & & & 5906 & \\
\hline Bonanza & 5226 & 6928 & 6688 & 5250 & 6176 & 6054 & \\
\hline Fairfield & 5446 & 6775 & 6511 & 5640 & 6050 & 6085 & \\
\hline Johnston & & & & 6871 & 6646 & 6758 & \\
\hline Halton & & & & & & & \\
\hline \multicolumn{8}{|l|}{ Wheat } \\
\hline$\overline{\text { Glenlea }}$ & 6041 & 7335 & 6845 & 5457 & 6313 & 6398 & \multirow{3}{*}{$\begin{array}{r}\text { (wheat } \\
6197 \text { ) }\end{array}$} \\
\hline Pitic & 5960 & 7676 & 7073 & 5759 & 5988 & 6491 & \\
\hline Neepawa & & & & 5703 & & 5703 & \\
\hline \multicolumn{8}{|l|}{ Rye } \\
\hline Petkus II & & & 7149 & 6011 & 7226 & 6795 & \multirow{3}{*}{$\begin{array}{l}\text { (rye } \\
5919)\end{array}$} \\
\hline Gazelle & 4793 & 7245 & & & & 6019 & \\
\hline Prolific & 3217 & 6667 & & & & 4942 & \\
\hline \multicolumn{8}{|l|}{ Triticale } \\
\hline$\overline{\text { Triwell }}$ & & & 7821 & 6922 & 7062 & 7268 & \multirow{4}{*}{$\begin{array}{l}\text { (triticale } \\
6615)\end{array}$} \\
\hline & & & & 6589 & & 6589 & \\
\hline Rosner & 5234 & 7004 & 6995 & 6167 & & 6350 & \\
\hline Welsh & 5462 & 6995 & 6305 & & & 6254 & \\
\hline \multicolumn{8}{|l|}{ Oat } \\
\hline Foothill & 7978 & 9715 & 7996 & 7899 & 8234 & 8364 & \multirow{8}{*}{$\begin{array}{l}\text { (oat } \\
8098)\end{array}$} \\
\hline Fraser & 7502 & 9618 & 7627 & 7625 & 8478 & 8170 & \\
\hline Grizzly & 7367 & 8926 & 7384 & 7669 & 7890 & 7847 & \\
\hline Harmon & & & 7710 & 7588 & & 7649 & \\
\hline Laurent & & & 8553 & 7729 & 7893 & 8058 & \\
\hline Cascade & & & & 7519 & & 7519 & \\
\hline Sentinel & & & & & 8791 & 8791 & \\
\hline $0 A 330-60$ & & & & & 8383 & 8383 & \\
\hline \multicolumn{8}{|l|}{ Other } \\
\hline Corn & & & 5875 & 5076 & 5659 & & 5537 \\
\hline Faba bean & 3865 & 4413 & 5283 & 5613 & 5709 & 4977 & 4977 \\
\hline Pea & 4333 & 4393 & 5184 & 5930 & 5812 & 5130 & 5130 \\
\hline Sunflower & 6147 & 3547 & 9837 & 7120 & 9570 & 7244 & 7244 \\
\hline
\end{tabular}


Table 3. Silage yield of annual forage crops and as a percentage of Foothill oat on three soil types

Crop

Black soils

15 stn.-years

$(\mathrm{kg} / \mathrm{ha})(\%)$
Grey Wooded soils

$\frac{15 \text { stn.-years }}{(\mathrm{kg} / \mathrm{hag})}$
Solonetzic soil

3 stn.-years

Barley

Betzes

Klondike

Bonanza

Fairfield

Johnston

Halton

6994

7455

7696

7472

8628

7995

72

77

80

77

89

83

4707

4662

4960

5241

5554

5410

83

5132

81

71

5400

4199

86

76

5608

4693

4034

60
63

62

66

70

74

72
3406

4485

5073

5851

5019
58

77

87

100

86

Rye

Petkus II

Gazelle

Prolific

7345

5849

75

63

69
72

4622

79

56

5306

91

6586

113

Triticale

Triwell

598

Rosner

Welsh

9169

8118

95

6170

4423

7653

84

79

$\begin{array}{ll}5 & 179\end{array}$

78

5383

83

59

69

7500

72

5607

96

54

\section{Oat}

Foothill

Fraser

Grizzly

Harmon

Laurent

Cascade

Sentinel

OA330-60

9669

9835

100

9236

$\begin{array}{ll}9 & 123\end{array}$

9681

9814

11279

11806

102

7466

7084

100

95

7000

96

94

6819

100

$\begin{array}{ll}7 & 098\end{array}$

101

5730

117

7701

122

7560

94

91

95

77

103

101

5054

86

9347

160

5481

2983

94

51

\section{other}

Corn

Faba bean

Pea

Sunflower

$\begin{array}{ll}8 & 032\end{array}$

$\begin{array}{ll}6 & 187\end{array}$

5494

8819

83

5013

4399

64

4904

91

6444

67

59

66

5842

100

$\begin{array}{lll}6 & 451\end{array}$

110

5302

91

5893

101

$\begin{array}{ll}6 & 131\end{array}$

105

6476

111

6834

117

4668

80 
Table 4. Silage yields of annual forage crops at Lacombe, in kilograms per hectare

\begin{tabular}{|c|c|c|c|c|c|c|}
\hline \multirow[b]{2}{*}{ Crop } & \multirow[b]{2}{*}{1979} & \multirow[b]{2}{*}{1980} & \multirow[b]{2}{*}{1981} & \\
\hline & & & & 1982 & 1983 & Averag \\
\hline \multicolumn{7}{|l|}{ Barley } \\
\hline Betzes & 6480 & 8426 & & & & 7453 \\
\hline Klondike & 8236 & 10420 & 10192 & & & 9616 \\
\hline Bonanza & 7603 & 10681 & 10316 & 8900 & 9676 & 9435 \\
\hline Fairfield & 7376 & 7314 & 9990 & 8213 & 8755 & 8329 \\
\hline Johnston & & & & 11212 & 8120 & 9666 \\
\hline Halton & & & & & 10856 & \\
\hline
\end{tabular}

\begin{tabular}{|c|c|c|c|c|c|c|}
\hline Wheat & & & & & & \\
\hline Glenlea & 9397 & 11537 & 10908 & 8397 & 10739 & 10195 \\
\hline $\begin{array}{l}\text { Pitic } \\
\text { Neepawa }\end{array}$ & 9212 & 11618 & 10629 & $\begin{array}{ll}6 & 220 \\
8 & 190\end{array}$ & 8720 & 9279 \\
\hline
\end{tabular}

\section{Rye}

Petkus II

Gazelle

Prolific

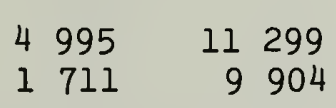

12100

7529

11284

10304

8147

5807

$\frac{\text { Triticale }}{\text { Triwell }}$

598

Rosner

Welsh

oat

Foothill

Fraser

Grizzly

Harmon

Laurent

Cascade

Sentinel

OA330-60 $\begin{array}{llll}12 & 015 & 10 & 787\end{array}$

10188

11646

9886

9472

11032

11278

$\begin{array}{ll}7860 & 9868\end{array}$

10510

8180

9910

12183

11389

11808

II 532

11364

10036

11883

$\begin{array}{lll}13 & 013\end{array}$

11634

12634

11840

10358

9141

12413

11802

10952

10933

12112

11408

14419

10430

11718

10508

11760

11785

12689

14909

\section{Other \\ Corn}

Faba bean

Pea

Sunflower
5616

3937

9270
$13 \quad 343$

5520

4098

4513
9644

6830

13562
8267

9140

6992

13223
$10 \quad 226$

9220

4341

15629
10612

7828

5239

11239 
Table 5. Silage yields of annual forage crops at Westlock, in kilograms per hectare

\begin{tabular}{|c|c|c|c|c|c|c|}
\hline Crop & 1979 & 1980 & 1981 & 1982 & 1983 & Average \\
\hline \multicolumn{7}{|l|}{ Barley } \\
\hline$\overline{\text { Betzes }}$ & 6747 & 5996 & & & & 6371 \\
\hline Klondike & 6597 & $\begin{array}{ll}5 & 137\end{array}$ & 5317 & & & 5683 \\
\hline Bonanza & 6312 & 5540 & 5903 & 4837 & 6636 & 5845 \\
\hline Fairfield & 6707 & 5688 & 6233 & 6465 & 6526 & 6323 \\
\hline Johnston & & & & 6253 & 6852 & 6552 \\
\hline Halton & & & & & 4467 & \\
\hline \multicolumn{7}{|l|}{ Wheat } \\
\hline$\overline{\text { Glenlea }}$ & 7496 & 4394 & 4688 & 4394 & 6956 & 5585 \\
\hline Pitic & 7966 & 4935 & 5394 & 5492 & 4722 & 5901 \\
\hline \multicolumn{7}{|l|}{ Neepawa } \\
\hline \multicolumn{7}{|l|}{ Rye } \\
\hline$\overline{\text { Petkus II }}$ & & & 5185 & 4985 & 5768 & 5312 \\
\hline Gazelle & 7965 & 5170 & & & & 6567 \\
\hline Prolific & 6349 & 5237 & & & & 5793 \\
\hline \multicolumn{7}{|l|}{ Triticale } \\
\hline Triwell & & & 6572 & 7460 & 6081 & 6704 \\
\hline 598 & & & & 7945 & & \\
\hline Rosner & 6898 & 4965 & 4457 & 5770 & & 5522 \\
\hline Welsh & 7613 & 4792 & 4221 & & & 5542 \\
\hline \multicolumn{7}{|l|}{ oat } \\
\hline Foothill & 9773 & 6378 & 6767 & 7971 & 6824 & 7542 \\
\hline Fraser & 9041 & 6657 & 5743 & 7125 & 8002 & 7313 \\
\hline Grizzly & 8776 & 6413 & 5014 & 7520 & 7132 & 6971 \\
\hline Harmon & & & 6592 & 6923 & & 6757 \\
\hline Laurent & & & 6654 & 7333 & 6188 & 6725 \\
\hline Cascade & & & & 6788 & & \\
\hline Sentinel & & & & & 9064 & \\
\hline OA330-60 & & & & & 10140 & \\
\hline \multicolumn{7}{|l|}{ other } \\
\hline Corn & & & 5190 & 7755 & 11137 & \\
\hline Faba bean & 6553 & 4059 & 3690 & 5764 & 5746 & 5162 \\
\hline Pea & 5913 & 4402 & 5784 & 6638 & 5780 & 5703 \\
\hline Sunflower & 6565 & 3316 & 10249 & 9191 & 11088 & 8081 \\
\hline
\end{tabular}


Table 6. Silage yields of annual forage crops at 0lds in 1979-1980 and Didsbury 1981-1983, in kilograms per hectare

\begin{tabular}{|c|c|c|c|c|c|c|}
\hline Crop & 1979 & 1980 & 1981 & 1982 & 1983 & Averag \\
\hline \multicolumn{7}{|l|}{ Barley } \\
\hline$\overline{\text { Betzes }}$ & 4802 & 9512 & & & & 7157 \\
\hline Klondike & 5083 & 7803 & 8309 & & & 7065 \\
\hline Bonanza & 5016 & 9219 & 9239 & 6070 & 8514 & 7809 \\
\hline Fairfield & 5691 & 9985 & 8010 & 6644 & 8493 & 7764 \\
\hline Johnston & & & & 8876 & 10457 & 9666 \\
\hline Halton & & & & & 8663 & \\
\hline
\end{tabular}

\begin{tabular}{|c|c|c|c|c|c|c|}
\hline Wheat & & & & & & \\
\hline$\overline{\text { Glenlea }}$ & 6676 & 8370 & 10104 & 6815 & 10157 & 8424 \\
\hline Pitic & 6038 & 8468 & $10 \quad 047$ & $\begin{array}{l}7303 \\
7\end{array}$ & 9725 & 8316 \\
\hline Neepawa & & & & 7477 & & \\
\hline
\end{tabular}

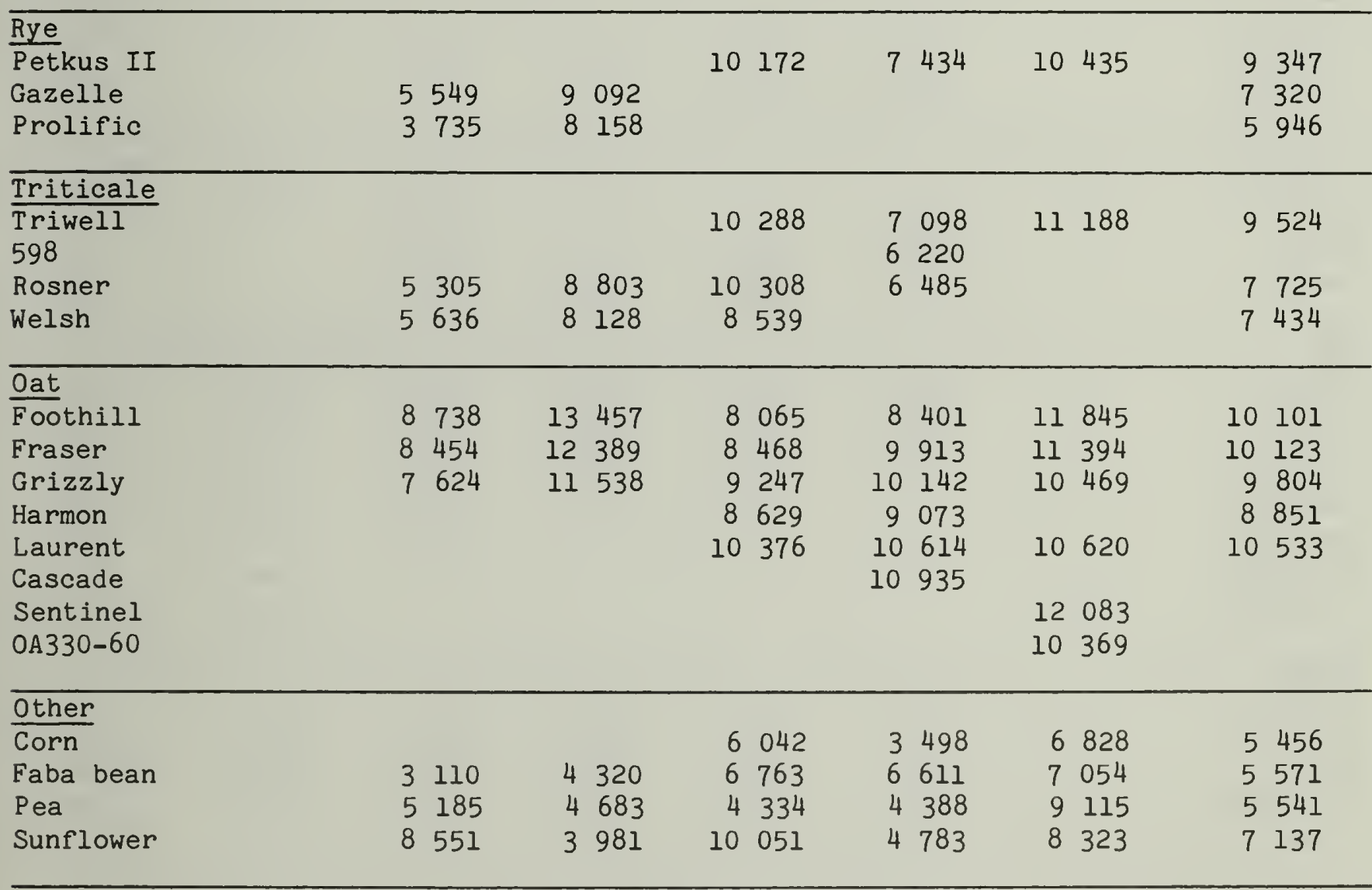


Table 7. Silage yields of annual forage crops at Bluffton, in kilograms per hectare Crop 1979 1980 1981 1982 1983 Average

\section{Barley}

Betzes

Klondike

Bonanza

Fairfield

Johnston

Halton

$3670 \quad 3741$

$3395 \quad 3068$

3358

3617

4393

5169

$\begin{array}{ll}3 & 433 \\ 4 & 792 \\ 4 & 618\end{array}$

4618

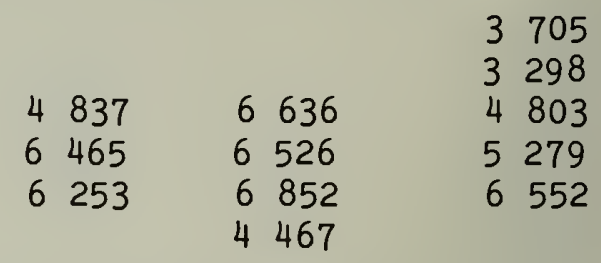

Wheat

Glenlea

Pitic

Neepawa

$2690 \quad 6545$

3500

6795

$\begin{array}{ll}7 & 124\end{array}$

4394

6956

5492

5722

5541

4864

5658

Rye

Petkus II

Gazelle

Prolific

Triticale

Triwell

598

Rosner

Welsh

Oat

Foothill

Fraser

Grizzly

Harmon

Laurent

Cascade

Sentinel

OA330-60 $\begin{array}{lllll}7222 & 4985 & 5768\end{array}$

5991

4002

3160 $\begin{array}{rr}1703 & 6301 \\ 601 & 5719\end{array}$
6804

$\begin{array}{llllll}6872 & 7460 & 6081\end{array}$

7945

$2777 \quad 6941 \quad 6745 \quad 5770$

5558

5249

\section{Other \\ Corn}

Faba bean

Pea

Sunflower
6824

8002

7132

6188

6923

7333

6788
7413

6973

$\begin{array}{ll}7 & 091\end{array}$

7319

6760

9064

10140 
Table 8. Silage yields of annual forage crops at Chedderville in 1979-1981 and Leslieville in 1982-1983, in kilograms per hectare

\begin{tabular}{|c|c|c|c|c|c|c|}
\hline Crop & 1979 & 1980 & 1981 & 1982 & 1983 & Average \\
\hline \multicolumn{7}{|l|}{ Barley } \\
\hline$\overline{\text { Betzes }}$ & 3814 & 4702 & & & & 4258 \\
\hline Klondike & 3521 & 4266 & 8251 & & & 5346 \\
\hline Bonanza & 3443 & 4516 & 9016 & 2567 & 5930 & 5094 \\
\hline Fairfield & 3737 & 5373 & 7837 & 2791 & 7219 & 5391 \\
\hline $\begin{array}{l}\text { Johnston } \\
\text { Halton }\end{array}$ & & & & 3545 & $\begin{array}{ll}8 & 395 \\
8 & 481\end{array}$ & 5970 \\
\hline \multicolumn{7}{|l|}{ Wheat } \\
\hline$\overline{\text { Glenlea }}$ & 3151 & 6033 & 7469 & 1761 & 4897 & 4662 \\
\hline Pitic & 2965 & 5923 & 8992 & 3059 & 5207 & 5229 \\
\hline Neepawa & & & & 3047 & & \\
\hline \multicolumn{7}{|l|}{ Rye } \\
\hline$\overline{\text { Petkus II }}$ & & & 6789 & 3698 & 7268 & 5918 \\
\hline Gazelle & 2386 & 3881 & & & & 3133 \\
\hline Prolific & 899 & 3431 & & & & 2165 \\
\hline \multicolumn{7}{|l|}{ Triticale } \\
\hline $\begin{array}{l}\text { Triwell } \\
598\end{array}$ & & & & $\begin{array}{ll}3 & 895 \\
2 & 191\end{array}$ & 6564 & \\
\hline Rosner & 1710 & 4732 & 7239 & 2792 & & 4118 \\
\hline Welsh & 1407 & 5622 & 6968 & & & 4665 \\
\hline \multicolumn{7}{|l|}{ Oat } \\
\hline Foothill & 5297 & 9132 & 9749 & $\begin{array}{ll}5 & 121\end{array}$ & 9990 & 7857 \\
\hline Fraser & 5276 & 8751 & 9652 & 4087 & 9840 & 7521 \\
\hline Grizzly & 5179 & 8491 & 9009 & 4877 & 9701 & 7451 \\
\hline Harmon & & & 8499 & 5215 & & 6857 \\
\hline Laurent & & & 9818 & 5477 & 10925 & 8740 \\
\hline Cascade & & & & 5038 & & \\
\hline Sentinel & & & & & 9761 & \\
\hline $0 A 330-60$ & & & & & 9054 & \\
\hline \multicolumn{7}{|l|}{ Other } \\
\hline Corn & & & 3556 & 3103 & 4800 & 3819 \\
\hline Faba bean & 2153 & 2817 & 5766 & 3272 & 6190 & 4039 \\
\hline Pea & 3217 & 5947 & 5671 & 4571 & 6984 & 5278 \\
\hline Sunflower & 4266 & 2511 & 8737 & 2567 & 8305 & 5277 \\
\hline
\end{tabular}


Table 9. Silage yields of annual forage crops at Smoky Lake, in kilograms per hectare

\begin{tabular}{|c|c|c|c|c|c|c|}
\hline Crop & 1979 & 1980 & 1981 & 1982 & 1983 & Average \\
\hline \multicolumn{7}{|l|}{ Barley } \\
\hline$\overline{\text { Betzes }}$ & 5474 & 6845 & & & & 6159 \\
\hline Klondike & 5394 & 6748 & 3884 & & & 5342 \\
\hline Bonanza & 5623 & 7221 & 4474 & 3141 & 4456 & 4983 \\
\hline \multirow{3}{*}{$\begin{array}{l}\text { Fairfield } \\
\text { Johnston } \\
\text { Halton }\end{array}$} & 5557 & 7118 & 5222 & 3416 & 3951 & 5052 \\
\hline & & & & 3426 & 4857 & 4141 \\
\hline & & & & & 3281 & \\
\hline \multicolumn{7}{|l|}{ Wheat } \\
\hline$\overline{\text { Glenlea }}$ & 6835 & 7131 & 4968 & 3902 & 3133 & 5193 \\
\hline Pitic & $\begin{array}{ll}6 & 078\end{array}$ & 7419 & 5508 & 4366 & 3202 & 5314 \\
\hline \multicolumn{7}{|l|}{ Neepawa } \\
\hline \multicolumn{7}{|l|}{ Rye } \\
\hline Petkus II & & & 5341 & 4509 & 4752 & 4867 \\
\hline Gazelle & 6162 & 7727 & & & & 6944 \\
\hline Prolific & 6005 & 7552 & & & & 6778 \\
\hline
\end{tabular}

Triticale

Triwell

598

Rosner

Welsh

Oat

Foothill

Fraser

Grizzly

Harmon

Laurent

Cascade

Sentinel

OA330-60 $\begin{array}{lllll}7376 & 4085 & 4124\end{array}$

5195

3132

$6855 \quad 6711 \quad 5493 \quad 4395$

5863

6235

$\begin{array}{llll}6885 & 6577 & 5245\end{array}$
Other
Corn
Faba bean
Pea
Sunflower
7863

6562

5779

7113

7550

5264

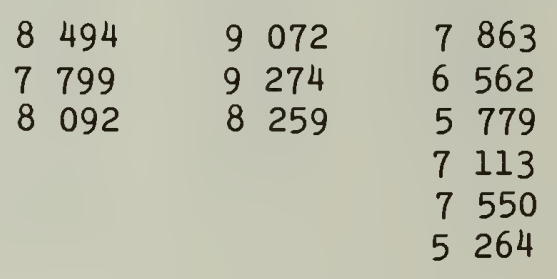

5828

5696

5284

5449

5409

4278

3485
4421

4383

4465

4880

$\begin{array}{ll}7 & 128\end{array}$

6759

6458

6281
5

5793 
Table 10. Silage yield of annual forage crops at Vegreville, in kilograms per hectare

\begin{tabular}{|c|c|c|c|c|}
\hline Crop & 1981 & 1982 & 1983 & Average \\
\hline $\begin{array}{l}\text { Barley } \\
\text { Klondike } \\
\text { Bonanza } \\
\text { Fairfield } \\
\text { Johnston } \\
\text { Halton }\end{array}$ & $\begin{array}{l}3406 \\
3077 \\
3666\end{array}$ & $\begin{array}{l}6110 \\
7618 \\
7714\end{array}$ & $\begin{array}{l}4268 \\
3937 \\
3988 \\
5019\end{array}$ & $\begin{array}{l}4485 \\
5073 \\
5851\end{array}$ \\
\hline $\begin{array}{l}\text { Wheat } \\
\text { Glenlea } \\
\text { Pitic } \\
\text { Neepawa }\end{array}$ & $\begin{array}{l}2654 \\
3059 \\
6586\end{array}$ & $\begin{array}{l}6786 \\
7874\end{array}$ & $\begin{array}{l}4428 \\
4986\end{array}$ & $\begin{array}{l}4622 \\
5306\end{array}$ \\
\hline $\begin{array}{l}\text { Rye } \\
\text { Petkus II }\end{array}$ & 3234 & 7399 & 6190 & 5607 \\
\hline $\begin{array}{l}\text { Triticale } \\
\text { Triwell } \\
598 \\
\text { Rosner } \\
\text { Welsh }\end{array}$ & $\begin{array}{l}2556 \\
3079 \\
2983\end{array}$ & $\begin{array}{l}7563 \\
9347 \\
7883\end{array}$ & 5044 & $\begin{array}{l}5054 \\
5481\end{array}$ \\
\hline $\begin{array}{l}\text { Oat } \\
\text { Foothill } \\
\text { Fraser } \\
\text { Grizzly } \\
\text { Harmon } \\
\text { Laurent } \\
\text { Cascade } \\
\text { Sentinel } \\
\text { OA330-60 }\end{array}$ & $\begin{array}{l}3594 \\
3443 \\
3314 \\
3308 \\
3891\end{array}$ & $\begin{array}{l}8043 \\
8275 \\
7432 \\
8478 \\
7960 \\
6476\end{array}$ & $\begin{array}{l}5891 \\
7637 \\
5161 \\
\\
6544 \\
6834 \\
4668\end{array}$ & $\begin{array}{l}5842 \\
6451 \\
5302 \\
5893 \\
6131\end{array}$ \\
\hline $\begin{array}{l}\text { Other } \\
\text { Corn } \\
\text { Faba bean } \\
\text { Pea } \\
\text { Sunflower }\end{array}$ & $\begin{array}{l}2762 \\
1931 \\
3867 \\
7129\end{array}$ & $\begin{array}{l}5985 \\
4182 \\
6384 \\
8901\end{array}$ & $\begin{array}{l}2227 \\
2865 \\
3639 \\
8305\end{array}$ & $\begin{array}{l}3658 \\
2992 \\
4630 \\
8111\end{array}$ \\
\hline
\end{tabular}


Table 11. Average percentage of protein of annual forages, 1980-1983

$\begin{array}{lllll}1980 & 1981 & 1982 & 1983 & \text { Average species yield }\end{array}$

\begin{tabular}{|c|c|c|c|c|c|c|}
\hline $\begin{array}{l}\text { Foothill } \\
\text { Fraser } \\
\text { Grizzly } \\
\text { Laurent } \\
\text { Harmon } \\
\text { Cascade } \\
\text { Sentinel } \\
\text { OA330-60 }\end{array}$ & $\begin{array}{l}6.3 \\
6.9 \\
7.1\end{array}$ & $\begin{array}{l}9.1 \\
8.7 \\
9.3 \\
8.6 \\
8.5\end{array}$ & $\begin{array}{l}7.3 \\
7.7 \\
7.6 \\
7.6 \\
7.6 \\
7.5\end{array}$ & $\begin{array}{l}7.9 \\
8.0 \\
8.3 \\
8.3 \\
\\
8.6 \\
7.9\end{array}$ & $\begin{array}{l}7.6 \\
7.8 \\
8.1 \\
8.2 \\
8.0 \\
7.5 \\
8.6 \\
7.9\end{array}$ & (oat 8.0) \\
\hline $\begin{array}{l}\text { Barley } \\
\text { Klondike } \\
\text { Bonanza } \\
\text { Betzes } \\
\text { Fairfield } \\
\text { Johnston } \\
\text { Halton }\end{array}$ & $\begin{array}{l}9.5 \\
9.3 \\
8.7 \\
9.0\end{array}$ & $\begin{array}{r}10.1 \\
9.7 \\
10.1\end{array}$ & $\begin{array}{l}9.9 \\
9.8 \\
8.4\end{array}$ & $\begin{array}{l}9.8 \\
9.8 \\
9.5 \\
9.0\end{array}$ & $\begin{array}{l}9.8 \\
9.7 \\
8.7 \\
9.7 \\
8.9 \\
9.0\end{array}$ & (barley 9.3) \\
\hline $\begin{array}{l}\text { Wheat } \\
\text { Glenlea } \\
\text { Pitic } \\
\text { Neepawa }\end{array}$ & $\begin{array}{l}8.0 \\
8.3\end{array}$ & $\begin{array}{l}9.5 \\
9.1\end{array}$ & $\begin{array}{l}8.8 \\
8.9 \\
9.1\end{array}$ & $\begin{array}{l}9.1 \\
9.2\end{array}$ & $\begin{array}{l}8.8 \\
8.9 \\
9.1\end{array}$ & (wheat 8.9 ) \\
\hline $\begin{array}{l}\text { Rye } \\
\text { Gazelle } \\
\text { Prolific } \\
\text { Petkus II }\end{array}$ & $\begin{array}{l}7.3 \\
7.5\end{array}$ & 7.7 & 7.8 & 7.9 & $\begin{array}{l}7.3 \\
7.5 \\
7.8\end{array}$ & (rye 7.5 ) \\
\hline $\begin{array}{l}\text { Triticale } \\
\text { Welsh } \\
\text { Rosner } \\
598 \\
\text { Triwell }\end{array}$ & $\begin{array}{l}8.5 \\
7.5\end{array}$ & $\begin{array}{l}9.2 \\
8.7 \\
7.8 \\
9.4\end{array}$ & 8.1 & 8.8 & $\begin{array}{l}8.8 \\
8.1 \\
7.8 \\
8.8\end{array}$ & $\begin{array}{l}\text { (triticale } \\
8.4 \text { ) }\end{array}$ \\
\hline $\begin{array}{l}\frac{\text { Other }}{\text { Diana faba bean }} \\
\text { Tara pea } \\
\text { Sundak sunflower } \\
\text { Corn }\end{array}$ & $\begin{array}{l}18.7 \\
16.5 \\
11.6\end{array}$ & $\begin{array}{r}18.7 \\
17.0 \\
9.9 \\
9.3\end{array}$ & $\begin{array}{r}17.9 \\
16.6 \\
8.9 \\
8.0\end{array}$ & $\begin{array}{r}16.1 \\
16.4 \\
9.7 \\
7.5\end{array}$ & $\begin{array}{r}17.8 \\
16.6 \\
10.0 \\
8.3\end{array}$ & \\
\hline
\end{tabular}


Table 12. Average protein yield of forage species over 4 years, in kilograms per hectare, at six locations in 1980 and seven locations in 1981-1983

\begin{tabular}{llllll}
\hline Crop & 1980 & 1981 & 1982 & 1983 & $\begin{array}{c}\text { Average of 27 } \\
\text { location-years }\end{array}$ \\
\hline Oat & $637(3) *$ & $681(5)$ & $595(6)$ & $686(6)$ & 650 \\
Barley & $604(4)$ & $617(3)$ & $575(3)$ & $599(4)$ & 599 \\
Wheat & $612(2)$ & $621(2)$ & $516(3)$ & $576(2)$ & 581 \\
Triticale & $560(2)$ & $628(3)$ & $526(3)$ & $627(1)$ & 585 \\
Rye & $514(2)$ & $542(1)$ & $483(1)$ & $590(1)$ & 532 \\
Sunflower & $411(1)$ & $948(1)$ & $557(1)$ & $873(1)$ & 697 \\
Faba bean & $825(1)$ & $915(1)$ & $1084(1)$ & $927(1)$ & 938 \\
Pea & $725(1)$ & $860(1)$ & $945(1)$ & $953(1)$ & 871 \\
Corn & - & $480(1)$ & $416(1)$ & $411(1)$ & 436 \\
\hline
\end{tabular}

* Figure in parentheses indicates number of cultivars. 
Table 13. Estimated average digestible energy yield of forage species over 4 years, in MCal/ha x 10-3, in six locations in 1980 and seven locations in 1981-1983

\begin{tabular}{llllll}
\hline Crop & 1980 & 1981 & 1982 & 1983 & $\begin{array}{l}\text { Average of } 27 \\
\text { location-years }\end{array}$ \\
\hline Oat & $24.2(3) *$ & $19.5(5)$ & $19.9(6)$ & $21.9(6)$ & 21.4 \\
Barley & $19.0(4)$ & $16.7(3)$ & $17.5(3)$ & $19.2(4)$ & 18.1 \\
Wheat & $21.5(2)$ & $17.4(2)$ & $15.6(3)$ & $18.3(2)$ & 18.2 \\
Triticale & $18.8(2)$ & $17.3(3)$ & $18.0(3)$ & $21.2(1)$ & 18.8 \\
Rye & $16.8(2)$ & $16.5(1)$ & $15.2(1)$ & $19.4(1)$ & 17.0 \\
Sunflowers & $9.6(1)$ & $23.3(1)$ & $18.3(1)$ & $26.0(1)$ & 19.3 \\
Faba bean & $11.6(1)$ & $12.7(1)$ & $16.4(1)$ & $16.0(1)$ & 14.2 \\
Pea & $11.6(1)$ & $13.2(1)$ & $17.0(1)$ & $17.5(1)$ & 14.8 \\
Corn & $-16.5(1)$ & $14.3(1)$ & $17.2(1)$ & 16.0 \\
\hline
\end{tabular}

* Figure in parentheses indicates number of cultivars. 
Table 14. Pasture yields at Lacombe and Bluffton, 1979-1983, in kilograms per hectare of dry matter

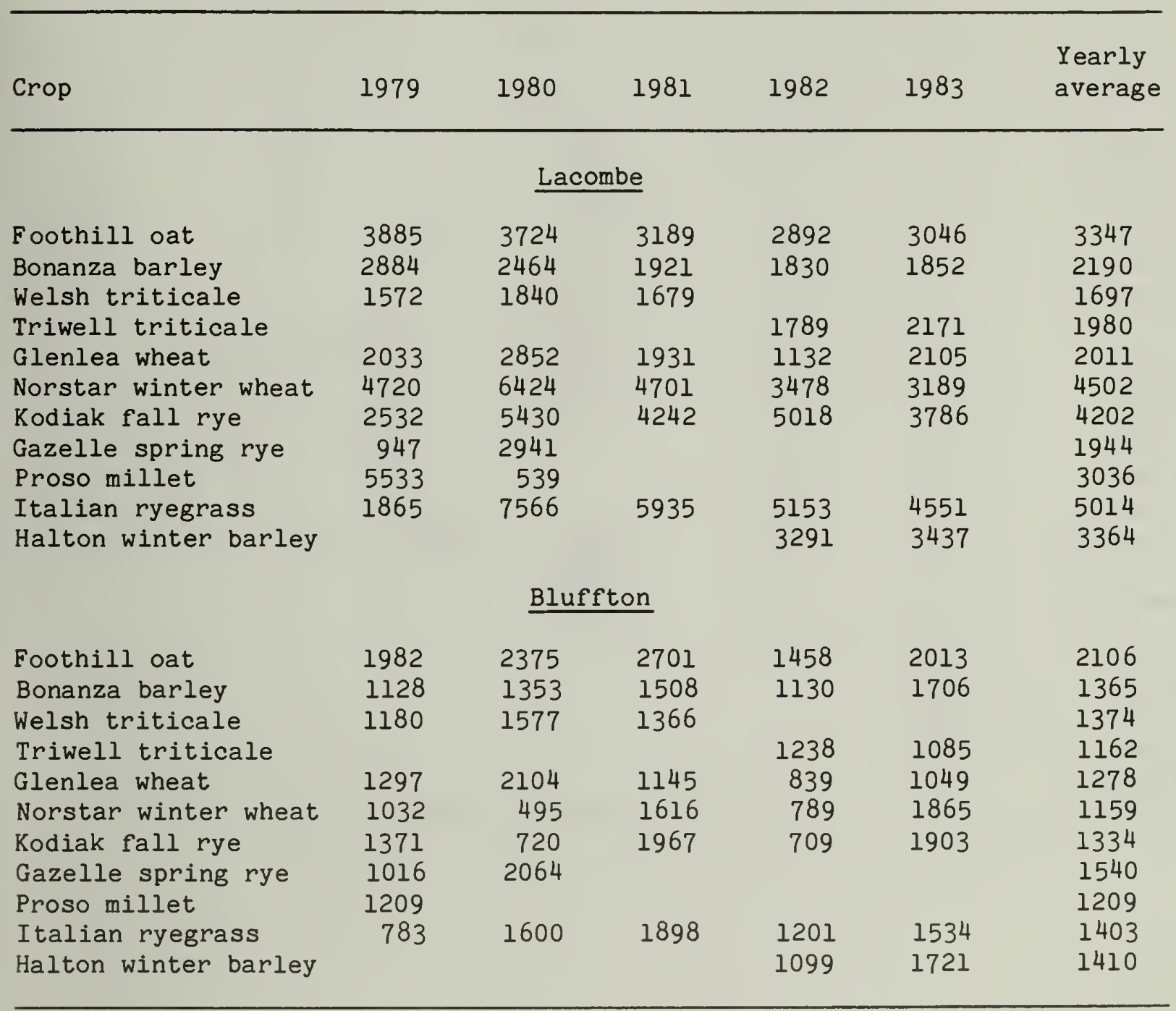


Table 15. Silage yield of oat cultivars at Lacombe over 5 years, in kilograms per hectare

\begin{tabular}{|c|c|c|c|c|c|}
\hline Cultivar & 1979 & 1980 & 1981 & 1982 & 1983 \\
\hline Laurent & 11117 & 10252 & 12765 & 13641 & 9569 \\
\hline Harmon & 11028 & 8946 & 11473 & 11384 & 9979 \\
\hline Foothill & 10872 & 11039 & 10776 & 11828 & 9475 \\
\hline Hudson & 10710 & 9656 & 11043 & 12893 & 9167 \\
\hline Grizzly & 10453 & 8891 & 11471 & 12124 & \\
\hline Victory & 10447 & 9706 & 9972 & & \\
\hline Scott & 10355 & 9948 & 12226 & 12710 & 9106 \\
\hline Gemini & 10230 & 8991 & 10579 & & \\
\hline Eagle & 10101 & 9052 & 6550 & & \\
\hline Larain & 10079 & 7608 & 10855 & & \\
\hline Kelsey & 9929 & 9517 & & & \\
\hline Rodney & 9922 & 7521 & & & \\
\hline Fraser & 9807 & 9083 & 12542 & 12627 & \\
\hline Cascade & 9783 & 8575 & 12645 & 12889 & 8272 \\
\hline Athabasca & 9656 & 9205 & 10432 & & \\
\hline Garry & 9220 & & 8552 & & \\
\hline Random & 9112 & 9979 & 11060 & & \\
\hline Glen & 8967 & & & & \\
\hline Cavell & 8963 & & & & \\
\hline Terra & 8589 & & & & \\
\hline Hinoat & 8095 & & & & \\
\hline Pendek & 7795 & & & & \\
\hline Sentinel & & & 11849 & 13479 & \\
\hline
\end{tabular}


Table 16. Silage yield of oat cultivars and lines at Lacombe over 5 years, in kilograms per hectare

\begin{tabular}{|c|c|c|c|c|c|}
\hline Cultivar & 1979 & 1980 & 1981 & 1982 & 1983 \\
\hline $\begin{array}{l}\text { Foothill } \\
\text { OA348-44 }\end{array}$ & 10872 & 11039 & 10776 & 11828 & 9475 \\
\hline $0 A 330-60$ & & & 1099 & 14230 & \\
\hline$O A 330-44$ & & & & & 10320 \\
\hline $1863-515$ & & & & & 10659 \\
\hline $2088-524$ & & & & & 10882 \\
\hline Dula & $10 \quad 429$ & 10153 & 12139 & 12042 & 9783 \\
\hline Bianca & $10 \quad 258$ & 8061 & & & \\
\hline A lma & $10 \quad 229$ & 11154 & 11828 & 12194 & 9752 \\
\hline Natal & 9943 & 9400 & & & \\
\hline Vicar & 9803 & $10 \quad 289$ & 10161 & & \\
\hline Elgin & 9656 & 7594 & & & \\
\hline Leanda & 9572 & 7917 & & & \\
\hline Sioux & 8947 & & & & \\
\hline Lamar & & 9276 & 10176 & & \\
\hline Kalott & & 8741 & 10314 & & \\
\hline
\end{tabular}


Table 17. Silage yield of oat cultivars and lines at Bluffton, in kilograms per hectare

\begin{tabular}{llll}
\hline Cultivar & 1981 & 1982 & 1983 \\
\hline Laurent & 7487 & 4999 & 5750 \\
Harmon & 8024 & 5295 & 5551 \\
Foothill & 8685 & 6027 & 4126 \\
Hudson & 8165 & 5183 & 5343 \\
Grizzly & 7116 & 5123 & \\
Victory & 7718 & & 3527 \\
Dula & 7828 & 5283 & 5222 \\
Scott & 7716 & 5655 & 5804 \\
Alma & 7776 & 5248 & \\
Fraser & 7578 & 5368 & \\
Vicar & 7035 & & 5580 \\
Random & 7429 & 6517 & 6210 \\
OA330-60 & & 5397 & 5716 \\
Sentinel & & 4820 & 6048 \\
Cascade & & & \\
OA330-44 & & & \\
1863-515 & & & \\
2088-524 & & & \\
& & & \\
\hline
\end{tabular}


Table 18. Silage yield of barley cultivars at Lacombe over 5 years, in kilograms per hectare

\begin{tabular}{|c|c|c|c|c|c|}
\hline Cultivar & 1979 & 1980 & 1981 & 1982 & 1983 \\
\hline Johnston & & 9971 & 9336 & 9732 & 9794 \\
\hline Empress & & & & & 9010 \\
\hline Klages & 7341 & 9348 & 7408 & 8614 & 9665 \\
\hline Galt & 8170 & 7573 & $\begin{array}{ll}7 & 177\end{array}$ & & \\
\hline Hector & 7986 & 10210 & 6862 & 7334 & \\
\hline Klondike & 6992 & 8109 & & & \\
\hline Bonanza & 6547 & 10700 & 8343 & 8931 & 8425 \\
\hline Windsor & 7698 & 10217 & 7629 & 9058 & 8538 \\
\hline Betzes & 6967 & 9203 & & & \\
\hline Conquest & & 9099 & & & \\
\hline Centennial & 8467 & 10131 & 8512 & 7415 & 7992 \\
\hline Keystone & 7442 & 10285 & 7894 & 8932 & 9786 \\
\hline Unitan & 7026 & 11511 & 6963 & 8241 & \\
\hline Fairfield & 6516 & 10253 & 7034 & 8130 & \\
\hline Norbert & & & & & 9155 \\
\hline Diamond & & & & & 7092 \\
\hline Beacon & 6584 & 9097 & & & \\
\hline $\begin{array}{l}\text { Gateway } 63 \\
\text { olli }\end{array}$ & $\begin{array}{ll}6 & 996 \\
6 & 451\end{array}$ & 8982 & & & \\
\hline
\end{tabular}


Table 19. Silage yield of barley cultivars at Bluffton over 3 years, in kilograms per hectare

\begin{tabular}{llll}
\hline Cultivar & 1981 & 1982 & 1983 \\
\hline Johnston & 5780 & 4395 & 5664 \\
Centennial & 4616 & 2249 & 3557 \\
Windsor & 5289 & 3148 & 4511 \\
Bonanza & 4481 & 2407 & 3356 \\
Keystone & 4552 & 3191 & 4075 \\
Klages & 4960 & 2734 & 4233 \\
Unitan & 4639 & 2982 & \\
Hector & 4714 & 2703 & \\
Galt & 4227 & & 3682 \\
Fairfield & 4271 & 2957 & 4179 \\
Norbert & & & 3633 \\
Diamond & & & \\
Empress & & & \\
& & & \\
\hline
\end{tabular}


Table 20. Silage yield of wheat, rye, and triticale cultivars at Lacombe, in kilograms per hectare

\begin{tabular}{lllll}
\hline Crop & 1980 & 1981 & 1982 & 1983 \\
\hline
\end{tabular}

Red spring wheat

\begin{tabular}{|c|c|c|c|c|}
\hline Park & 9105 & & & \\
\hline Neepawa & 10579 & 12502 & 10831 & 9442 \\
\hline Manitou & 9733 & & & \\
\hline Sinton & 10122 & & & \\
\hline Thatcher & 10562 & 11032 & & \\
\hline Columbus & & & & 10094 \\
\hline
\end{tabular}

Utility wheat

\begin{tabular}{|c|c|c|c|c|}
\hline Glenlea & 10214 & 11533 & 11246 & 9753 \\
\hline Pitic & 11304 & 11111 & 10680 & \\
\hline Fielder & 9566 & & & \\
\hline
\end{tabular}

Durum wheat

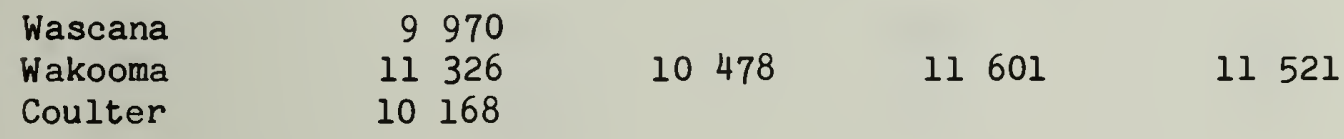

$\underline{\text { Triticale }}$

\begin{tabular}{|c|c|c|c|c|}
\hline Rosner & $10 \quad 027$ & 11560 & 11512 & 11674 \\
\hline Welsh & 9808 & 10915 & 8850 & 9142 \\
\hline Triwell & 12831 & 11350 & 13468 & 12153 \\
\hline Carman & & & & 13925 \\
\hline
\end{tabular}

Spring rye

$\begin{array}{lrrrr}\text { Gazelle } & 10553 & 11017 & 10925 \\ \text { Prolific } & 9879 & & & \\ \text { Petkus I } & 10923 & & & \\ \text { Petkus II } & 11491 & 10908 & 11208 \\ \text { Petkus III } & 8782 & & \end{array}$


Table 21. Silage yield of wheat, rye, and triticale cultivars at Bluffton over 3 years, in kilograms per hectare

\begin{tabular}{llll}
\hline Crop & 1981 & 1982 & 1983 \\
\hline
\end{tabular}

\section{Wheat}

$\begin{array}{llll}\text { Neepawa } & 4914 & 3045 & 3444 \\ \text { Glenlea } & 5124 & 2778 & 3171 \\ \text { Pitic } & 5016 & 3359 & \\ \text { Thatcher } & 4582 & & \\ \text { Wakooma } & 4162 & 3246 & 2905 \\ \text { Columbus } & & & 3677\end{array}$

Spring rye

$\begin{array}{lll}\text { Gazelle } & 4138 & 2600 \\ \text { Petkus II } & 5337 & 3431\end{array}$

Triticale

Triwell 6300

4388

3961

5269

Rosner

4712

3171

5490

Welsh

2251

4318

5226

Carman 
Table 22. Silage yield of sunflower cultivars at Lacombe over 5 years, in kilograms per hectare

\begin{tabular}{|c|c|c|c|c|c|c|}
\hline Cultivar & 1979 & 1980 & 1981 & 1982 & 1983 & Average \\
\hline Sundak & 7713 & 4222 & 8090 & 13477 & 14499 & 9600 \\
\hline Sputnik & 10940 & 4524 & 10485 & 8822 & 11281 & 9210 \\
\hline Sungro $372 \mathrm{~A}$ & 11719 & 8958 & 11205 & 11257 & 15231 & 11674 \\
\hline Sungro 380 & & 12944 & 8939 & 9628 & 13011 & 11130 \\
\hline Kenya White & & 5167 & 18393 & 14581 & & 12714 \\
\hline Hybrid 894 & & 5911 & 11891 & 8657 & & 8820 \\
\hline $81-1110-2$ & & & & 11650 & 16687 & $14 \quad 168$ \\
\hline $81-1421$ & & & & 14081 & 15295 & 14688 \\
\hline Jerusalem artichoke & 5115 & 3585 & & & & 4350 \\
\hline & & & & & 13194 & 13194 \\
\hline $82-245$ & & & & & 9354 & 9354 \\
\hline Dahlgren 135 & & & & & 17892 & 17892 \\
\hline Super 500 & & & & & $17 \quad 358$ & $17 \quad 358$ \\
\hline
\end{tabular}


Table 23. Silage yield of faba bean at Lacombe over 4 years, in kilograms per hectare

\begin{tabular}{|c|c|c|c|c|c|}
\hline Cultivar & 1980 & 1981 & 1982 & 1983 & $\begin{array}{l}\text { 4-year } \\
\text { average }\end{array}$ \\
\hline Diana & 6092 & 11110 & 8029 & 10417 & 8912 \\
\hline Herz Freya & 6441 & 14308 & 13054 & 10687 & 11122 \\
\hline Aladin & 7754 & 8581 & 12206 & 11076 & 9904 \\
\hline Outlook & & 13053 & 11614 & 11401 & 12023 \\
\hline Ackerperle & 4553 & & & & 4553 \\
\hline Orion & 5541 & 10724 & 6122 & 8335 & 7680 \\
\hline Lacombe 非 3 & 4481 & 9578 & 6221 & 9061 & 7335 \\
\hline
\end{tabular}


Table 24. Silage yield of faba bean at Bluffton and Vegreville in kilograms per hectare

\begin{tabular}{lcccccc}
\hline & \multicolumn{3}{c}{ Bluffton } & \multicolumn{2}{c}{ Vegreville } \\
\cline { 2 - 4 } Cultivar & 1981 & 1982 & 1983 & & 1982 & 1983 \\
\hline Diana & 3353 & 5992 & 3841 & 4444 & 2205 \\
Herz Freya & 4147 & 6321 & 3573 & 6055 & 2314 \\
Aladin & 2935 & 7642 & 4122 & 6156 & 2202 \\
Outlook & 2980 & 7071 & 3359 & 5859 & 2072 \\
Orion & 3827 & 4637 & 3630 & 3677 & 1348 \\
Lacombe 3 & 3105 & 4245 & 3078 & 4769 & 1289 \\
\hline
\end{tabular}


Table 25. Silage yield of pea cultivars at Lacombe over 4 years, in kilograms per hectare

\begin{tabular}{llllll}
\hline Cultivar & 1980 & 1981 & 1982 & 1983 \\
\hline Tara & 6955 & 7919 & 10373 & 10612 \\
Trapper & 6610 & 7592 & 11417 & 6653 \\
Century & 5713 & 8 & 622 & & 8566 \\
Lenca & & 8362 & & 7289 \\
Triumph & & 6540 & & 5 & 730 \\
& & & & & \\
\hline
\end{tabular}


Table 26. Silage yield of corn at Lacombe over 3 years, in kilograms per hectare

\begin{tabular}{|c|c|c|c|}
\hline Cultivars & 1981 & 1982 & 1983 \\
\hline Stewart 3502 & 15662 & & \\
\hline Morden 7G & 11983 & & \\
\hline $\begin{array}{l}\text { Pride Rl02 } \\
\text { G-4077 }\end{array}$ & $\begin{array}{l}19786 \\
11488\end{array}$ & & 2787 \\
\hline $\begin{array}{l}\text { Northrup King PX403 } \\
\text { Pioneer } 3995\end{array}$ & 11583 & $\begin{array}{rl}10 & 073 \\
8 & 556\end{array}$ & $\begin{array}{ll}3 & 446 \\
2 & 028\end{array}$ \\
\hline $\mathrm{AS}^{*}$ & & 12670 & \\
\hline DeKalb 182 & & 11073 & \\
\hline Pickseed 2555 & & 10997 & \\
\hline Limagrain GLG223* & 10783 & & \\
\hline Limagrain GLG152* & 10436 & & \\
\hline Pioneer 3994 & & 10425 & 3025 \\
\hline Limagrain $3^{*}$ & & 10146 & 2708 \\
\hline EDO & & 10023 & \\
\hline Asgrow RXI7 & & 9843 & 2891 \\
\hline Cargill PAG50I & & 9836 & \\
\hline Pickseed 2111 & & 9631 & \\
\hline Limagrain I* & & 9503 & \\
\hline $\mathrm{Br} 180^{*}$ & 9497 & & \\
\hline Pioneer 3993 & & 9485 & \\
\hline KWS $130 *$ & & 9272 & \\
\hline DeKalb 23 & & 9045 & \\
\hline Pride 1108 & & 8225 & \\
\hline Hyland 2200 & & & 3272 \\
\hline Pioneer 3996 & & & 2924 \\
\hline Pride R097 & & & 2580 \\
\hline Pickseed 2011 & & & 3435 \\
\hline
\end{tabular}

European hybrids 
Table 27. Silage yield of millets at Lacombe over 2 years, in kilograms per hectare

\begin{tabular}{llll}
\hline Cultivar & 1981 & 1982 & Average \\
\hline
\end{tabular}

Proso millet

\begin{tabular}{|c|c|c|c|}
\hline NC 22-36 & 10753 & 7945 & 9349 \\
\hline NC $22-50$ & $10 \quad 262$ & 7598 & 8930 \\
\hline NC 22-3 & 9643 & 6068 & 7856 \\
\hline NC 22-47 & 8929 & 6420 & 7674 \\
\hline NC $22-44 / 1$ & 8831 & 5867 & 7349 \\
\hline NC 22-14 & 8431 & 6149 & 7290 \\
\hline NC $22-17$ & 8294 & 5551 & 692 \\
\hline NC 22-44 & 8260 & 5424 & 684 \\
\hline NC $22-43$ & 8194 & 5496 & 684 \\
\hline NC 22-42 & 6762 & 5734 & 6248 \\
\hline
\end{tabular}

Foxtail millet

\begin{tabular}{|c|c|c|c|}
\hline NC 2l-9 & 11386 & 6536 & 8961 \\
\hline NC $21-10$ & 11258 & $\begin{array}{ll}6 & 192 \\
7\end{array}$ & $\begin{array}{ll}8725 \\
8 & 552\end{array}$ \\
\hline NC $21-43 / 1$ & 9698 & 7406 & \\
\hline NC $21-42 / 1$ & 9032 & 6072 & 7552 \\
\hline NC $21-41 / 1$ & 8534 & 6471 & 750 \\
\hline NC $21-35$ & 8115 & 6183 & 7149 \\
\hline NC $21-21$ & 7831 & 5465 & 664 \\
\hline NC $21-20$ & 7384 & 5122 & 625 \\
\hline
\end{tabular}


Table 28. Forage yield of ryegrass cultivars at Lacombe over 3 years, in kilograms per hectare

\begin{tabular}{|c|c|c|c|c|}
\hline Cultivar & 1981 & 1982 & 1983 & $\begin{array}{l}3 \text {-year } \\
\text { average }\end{array}$ \\
\hline \multicolumn{5}{|c|}{ Silage (two cuts) } \\
\hline $\begin{array}{l}\text { Lemtal } \\
\text { Promenade } \\
\text { Maris Ledger } \\
\text { Merwester }\end{array}$ & $\begin{array}{rr}10 & 141 \\
10 & 612 \\
10 & 935 \\
9 & 277\end{array}$ & $\begin{array}{rr}7 & 627 \\
11 & 210 \\
6 & 720 \\
8 & 528\end{array}$ & $\begin{array}{ll}7 & 183 \\
8 & 750 \\
8 & 364 \\
8 & 327\end{array}$ & $\begin{array}{rr}8 & 317 \\
10 & 191 \\
8 & 673 \\
8 & 711\end{array}$ \\
\hline \multicolumn{5}{|c|}{ Hay (three cuts) } \\
\hline $\begin{array}{l}\text { Lemtal } \\
\text { Promenade } \\
\text { Maris Ledger } \\
\text { Merwester }\end{array}$ & $\begin{array}{rr}10 & 494 \\
9 & 873 \\
9 & 733 \\
8 & 665\end{array}$ & $\begin{array}{ll}8 & 838 \\
8 & 534 \\
9 & 276 \\
9 & 867\end{array}$ & $\begin{array}{ll}4 & 478 \\
4 & 796 \\
5 & 373 \\
5 & 891\end{array}$ & $\begin{array}{ll}7 & 937 \\
7 & 734 \\
8 & 127 \\
8 & 141\end{array}$ \\
\hline \multicolumn{5}{|c|}{ Pasture (four or five cuts) } \\
\hline $\begin{array}{l}\text { Lemtal } \\
\text { Promenade } \\
\text { Maris Ledger } \\
\text { Merwester }\end{array}$ & $\begin{array}{ll}6 & 389 \\
5 & 996 \\
7 & 602 \\
5 & 653\end{array}$ & $\begin{array}{ll}3 & 917 \\
4 & 669 \\
5 & 006 \\
5 & 217\end{array}$ & $\begin{array}{ll}3 & 358 \\
3 & 568 \\
3 & 362 \\
3 & 564\end{array}$ & $\begin{array}{ll}4 & 555 \\
4 & 744 \\
5 & 323 \\
4 & 811\end{array}$ \\
\hline
\end{tabular}


Table 29. Pasture yield of winter wheat, triticale, and fall rye at Lacombe in 1983, in kilograms per hectare

\begin{tabular}{lcccc}
\hline & \multicolumn{4}{c}{ Days from seeding to cut } \\
\cline { 2 - 5 } Crop & 71 & 102 & 147 & Total \\
\hline Sundance winter wheat & 1917 & 1096 & 432 & 3446 \\
Winalta winter wheat & 1541 & 1467 & 607 & 3616 \\
Norstar winter wheat & 1031 & 1023 & 324 & 2379 \\
Kodiak fall rye & 1684 & 828 & 380 & 2893 \\
Puma fall rye & 1260 & 1008 & 562 & 2832 \\
Cougar fall rye & 1277 & 1076 & 624 & 2978 \\
Frontier fall rye & 1246 & 940 & 505 & 2692 \\
Wintri winter triticale & 975 & 1054 & 571 & 2602 \\
& & & & \\
\hline
\end{tabular}


Table 30. Forage yield of brassica species at Lacombe in 1982 as dry matter, in kilograms per hectare

\begin{tabular}{|c|c|c|c|c|c|}
\hline \multirow[b]{2}{*}{ Cultivar } & \multirow{2}{*}{$\begin{array}{l}\text { Silage } \\
\text { yield* }\end{array}$} & \multirow{2}{*}{$\begin{array}{l}\text { Days to } \\
\text { first cut }\end{array}$} & \multicolumn{3}{|c|}{ Pasture yield } \\
\hline & & & Cut 1t & Cut $2 *$ & Total \\
\hline Maris Kestrel & 6078 & 124 & 2801 & 372 & 3173 \\
\hline Merlin kale & 6961 & 124 & 2288 & 258 & 2546 \\
\hline Bittern kale & 6588 & 124 & 1739 & 33 & 1772 \\
\hline Condor kale & 9008 & 124 & 2953 & 0 & 2953 \\
\hline Tema kale & 7548 & 124 & 2610 & 91 & 2700 \\
\hline Angerro kale & 6324 & 124 & 1047 & 275 & 1322 \\
\hline English Marrowstem kale & 3296 & 124 & 902 & 72 & 974 \\
\hline Brassica napus IR-022 & 4976 & 81 & $4549+$ & 450 & 4999 \\
\hline Brassica napus sinus & 1526 & 81 & $308+$ & 0 & 308 \\
\hline Nevin forage rape & 6450 & 124 & 5032 & 454 & 5486 \\
\hline Appin grazing turnip & 4217 & 124 & 3646 & 703 & 4349 \\
\hline Neris fodder radish & 4803 & 81 & $4590+$ & 489 & 5079 \\
\hline Rauola oilseed radish & 6677 & 81 & $6484 t$ & 0 & 6484 \\
\hline Dwarf Essex forage rape & 2770 & 124 & 1368 & 364 & 1732 \\
\hline English Broadleaf & 6023 & 124 & 1458 & 0 & 1458 \\
\hline Candle canola & 4609 & 81 & $5005+$ & 0 & 5005 \\
\hline Altex canola & 5207 & 81 & $5056 t$ & 206 & 5262 \\
\hline
\end{tabular}

* Cut on 1 October.

+ Cut on 29 July. Others in the same column cut on 10 September. 
Table 31. Forage yield of brassica species at Lacombe in 1983 as dry matter, in kilograms per hectare

\begin{tabular}{|c|c|c|c|c|c|c|c|c|}
\hline \multirow[b]{2}{*}{ Cultivar } & \multicolumn{3}{|c|}{ Silage yield } & \multicolumn{5}{|c|}{ Pasture yield } \\
\hline & Cut $1^{*}$ & Cut 2 & Total & Cut It & & Cut & 2 Cut 3 & 3 Total \\
\hline Maris Kestrel & 16780 & 0 & 16780 & 1808 & & 827 & 0 & 2635 \\
\hline Merlin kale & 16698 & 0 & 16698 & 1214 & 1 & 189 & 0 & 2403 \\
\hline Bittern kale & 11994 & 0 & 11994 & 2397 & & 531 & 0 & 2928 \\
\hline Condor kale & 11697 & 0 & 11697 & 4529 & & 951 & 0 & 5480 \\
\hline Tema kale & 10360 & 0 & 10360 & 950 & & 508 & 0 & 1458 \\
\hline Nevin forage rape & 14044 & 0 & 14044 & 2788 & & 741 & 1272 & 4801 \\
\hline Appin grazing turnip & 15244 & 0 & 15244 & 2436 & 1 & 747 & 813 & 4996 \\
\hline Neris fodder radish & $10343 *$ & 5965 & 16308 & 2343 & 1 & 247 & 1513 & 5103 \\
\hline Altex canola & 9 523* & 866 & 10389 & 2476 & & 462 & 1884 & 4822 \\
\hline Apoll oil radish & $13964 *$ & 895 & 14895 & 3355 & & 389 & 2492 & 6236 \\
\hline Crail fodder radish & 15916 & 0 & 15916 & 2154 & 1 & 137 & 953 & 4244 \\
\hline Caron forage rape & 16630 & 0 & 16630 & 2585 & & 674 & 711 & 3970 \\
\hline Dinas forage rape & 24085 & 0 & 24085 & 2106 & 1 & 762 & 0 & 3868 \\
\hline Tobin canola & $11385^{*}$ & 0 & 11385 & 1344 & 1 & 125 & 0 & 2469 \\
\hline Gruner angiliter & 9205 & 0 & 9205 & 654 & 1 & 020 & 0 & 1674 \\
\hline
\end{tabular}

* Cut on 29 July. Others in same column cut on 14 September. + Cut on 4 July. 


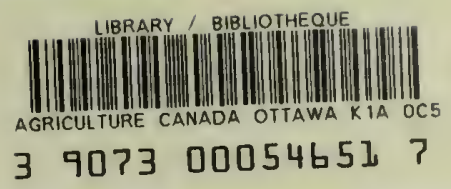


